\title{
PEMBUATAN MOBILE TOUR GUIDE MUSEUM SANGIRAN DENGAN AUGMENTED REALITY BERBASIS MARKERLESS TRACKING
}

\author{
Fendi Aji Purnomo \\ Fakultas MIPA, Program Diploma 3 Teknik Informatika \\ Universitas Sebelas Maret \\ Email: fendi_aji@mipa.uns.ac.id \\ Eko Harry Pratisto \\ Fakultas MIPA, Program Diploma 3 Teknik Informatika \\ Universitas Sebelas Maret \\ eko.harry@gmail.com \\ Hartatik \\ Fakultas MIPA, Program Diploma 3 Teknik Informatika \\ Universitas Sebelas Maret \\ Agus Purbayu \\ Fakultas MIPA, Program Diploma 3 Teknik Informatika \\ Universitas Sebelas Maret \\ Hana Septi Ariani \\ Fakultas MIPA, Program Diploma 3 Teknik Informatika \\ Universitas Sebelas Maret
}

\begin{abstract}
ABSTRAK
Museum Purbakala Sangiran merupakan salah satu museum yang menyimpan benda purbakala. Digitalisasi objek purbakala merupakan salah satu usaha pelestarian yang dilakukan. Tujuan dari penelitian ini adalah untuk melakukan digitalisasi informasi benda-benda purbakala di ruang pamer Museum Sangiran dengan menggunakan teknologi Augmented reality berbasis Android. Metodologi penelitian dalam pengembangan Augmented reality untuk Mobile Guide Museum Sangiran menggunakan metode waterfall, yaitu tahap analisis, perancangan, desain \& script, serta pengujian dilakukan melalui survey kuisioner. Analisis pengujian aplikasi terhadap daya tarik pengunjung dilakukan berbasis angket kuisioner dengan skala butir pertanyaan menggunakan skala Likert dengan skala 6. Hasil analisis berupa validitas dan realibilitas menghasilkan alpha cronbach 0,97 sehingga semua butir pertanyaan dinyatakan valid dan reliable. Tanggapan responden terhadap aplikasi Mobile Guide Museum Sangiran bernilai setuju-sangat setuju diwujudkan dalam 5 aspek yaitu ketertarikan terhadap aplikasi 93\%, kemudahan mendapatkan informasi 97\%, kemudahan navigasi 100\%, interaktifitas aplikasi 94\%, dan inovasi aplikasi $97 \%$.
\end{abstract}

Kata kunci: benda purbakala, markerless, mobile augmented reality.

\begin{abstract}
Sangiran Archeological Museum is a museum that holds archaeological objects. Digitalization of ancient objects is one of the conservation efforts undertaken. The aim of this study is to conduct information digitization of ancient objects in the showroom Museum Sangiran using Augmented Reality technology based on Android. The development of Augmented Reality for Mobile Guide Museum Sangiran using waterfall method which are analysis phase, design, design and script, as well as the testing by questionnaire survey. The analysis of application test against a visitor attraction based on questionnaire using Likert scale with scale of 6. The result of the analysis of the validity and reliability produce Cronbach alpha of 0.97 where all the questions declared are valid and reliable. The respond of Mobile Guide Museum Sangiran which worth disagree-strongly agree embodied in five aspects: interest in the application with 93\%, the ease of getting information with 97\%, ease of navigation of 100\%, interactivity applications $94 \%$, and application innovation $97 \%$.
\end{abstract}

Keywords: archaeological objects, markerless, mobile augmented reality. 


\section{PENDAHULUAN}

Sangiran adalah sebuah situs purbakala yang mempunyai banyak sejarah-sejarah kehidupan pada jaman lebih dari 2 juta tahun yang lalu. Secara stratigrafis situs purbakala Sangiran merupakan situs manusia purba yang terlengkap di Asia yang kehidupannya dapat dilihat secara berurutan tanpa terputus sejak 2 juta tahun yang lalu yaitu sejak kala Pliosen Akhir hingga akhir Pleistosen Tengah [1]. Hal yang sangat menarik adalah berdasarkan penelitian bahwa manusia purba jenis Homo Erectus yang ditemukan di wilayah Sangiran sekitar lebih dari 100 individu yang mengalami masa evolusi tidak kurang dari 1 juta tahun. Dan ternyata jumlah ini mewakili 65\% dari seluruh fosil manusia purba yang ditemukan di Indonesia dan merupakan 50\% dari jumlah fosil sejenis yang ditemukan di dunia[2]. Keberadaan peninggalan bersejarah benda purbakala di Museum Sangiran semakin lama termakan waktu semakin tidak terawat dan mengalami kepunahan. Upaya pelestarian sudah dilakukan tetapi masih dalam media cetak atau dalam bentuk gambar, dan untuk mengakses informasi tersebut masyarakat harus datang ke lokasi. Alternatif supaya peninggalan manusia purba di Museum Sangiran dapat dikenal masyarakat yaitu perlu konsep digitalisasi objek purbakala yang efisien dan efektif sehingga masyarakat dapat melihat secara langsung dan keaslian benda purba di ruang pamer dapat terjaga.

Digitalisasi objek benda purbakala dapat menggunakan teknologi Augmented reality dalam 3D visual. Teknologi AR adalah sebuah teknologi visual yang menggabungkan objek atau dunia virtual ke dalam tampilan dunia nyata secara real time [3]. Teknologi AR telah dikembangkan dalam berbagai bidang seperti militer, kedokteran, pendidikan, teknik, industri hingga hiburan. Hal ini disebabkan oleh keunggulan teknologi AR yang memungkinkan pengguna untuk melakukan interaksi menggunakan gerak tubuhnya secara alami. Kamera sebagai 'mata' dari teknologi AR mengambil gambar dari marker tersebut secara berkelanjutan, memproses dan kemudian menghasilkan interaksi virtual yang tampak pada tampilan dunia nyata baik pada layar maupun Head Mounted Display (HMD).

Beberapa sistem AR yang telah dikembangkan didasarkan pada kemudahan untuk tracking marker, biasanya tercetak pada kertas. Teknik computer vision dapat digunakan secara akurat untuk menentukan posisi dan orientasi kartu serta memungkinkan sistem AR untuk menempatkan objek virtual pada kartu tersebut.

Marker merupakan ilustrasi hitam dan putih persegi dengan batas hitam tebal dan latar belakang putih. Komputer akan mengenali posisi dan orientasi marker dan menciptakan dunia virtual 3D yaitu titik $(0,0,0)$ dan 3 sumbu yaitu X,Y,dan Z. Marker Based Tracking ini sudah lama dikembangkan sejak tahun 80an dan pada awal 90an mulai dikembangkan untuk penggunaan Augmented reality [4].

Penelitian Augmented Reality untuk museum guide telah dikembangkan oleh Jing [5], penelitian tersebut membuat aplikasi berbasis Windows untuk museum guide yang diimplementasikan pada ultra mobile PC yang menggunakan USB kamera untuk tracking marker. Penelitian serupa juga telah dikembangkan oleh Nassar [6], yaitu pengembangan aplikasi AR pada iPhone untuk exhibition dengan menggunakan Artoolkitplus. Dalam penelitian ini akan dikembangkan aplikasi Augmented reality untuk Museum Sangiran berbasis android untuk mobile phone. Aplikasi yang dibuat melibatkan interaktivitas pengunjung dalam memunculkan objek virtual. Objek virtual yang akan dibuat merupakan informasi pelengkap benda purbakala koleksi Museum Sangiran yang berada di Ruang Pamer Museum. Pengembangan aplikasi tersebut menggunakan metode waterfall yang dimulai dengan inisialisasi, perancangan, pembuatan desain, script dan pengujian. Pengujian dilakukan secara black box yaitu mengujikan melalui tracking markerless yang telah ditentukan. Marker yang digunakan berupa objek 2D dan 3D di ruang pamer Museum Sangiran. Sebagai analisis kemanfaatan dilakukan penyebaran angket kuisioner terhadap pengunjung dengan 5 aspek penilaian meliputi aspek ketertarikan terhadap aplikasi, aspek kemudahan mendapatkan informasi, aspek kemudahan penggunaan navigasi, aspek interaktifitas aplikasi dan aspek inovasi aplikasi. Dalam mempertahankan nilai kelayakan butir pertanyaan pada kuisioner dilakukan uji validitas dan realibilitas terhadap data hasil kuisioner.

Validitas adalah tingkat kehandalan dan kesahihan alat ukur yang digunakan. Instrumen dikatakan valid berarti menunjukkan alat ukur yang dipergunakan untuk mendapatkan data itu valid atau dapat digunakan untuk mengukur apa yang seharusnya di ukur [7]. Dengan demikian, instrumen yang valid merupakan instrumen yang benar-benar tepat untuk mengukur apa yang hendak di ukur.

Uji reliabilitas berguna untuk menetapkan apakah instrumen yang dalam hal ini kuesioner dapat digunakan lebih dari satu kali, paling tidak oleh responden yang sama akan menghasilkan data yang konsisten. Dengan kata lain, reliabilitas instrumen mencirikan tingkat konsistensi. Banyak rumus yang dapat digunakan untuk mengukur reliabilitas diantaranya adalah Rumus Alpha cronbach sebagai berikut:

$\alpha=\left(\frac{K}{K-1}\right)\left(\frac{s_{F}^{2}-\sum s_{i}^{2}}{s_{x}^{2}}\right)$ 
Keterangan :

$$
\begin{aligned}
& \alpha=\text { koefisien reliabilitas alpha cronbach } \\
& K=\text { jumlah item pertanyaan yang diuji } \\
& \sum_{S_{x}^{2}} S_{i}^{2}=\text { jumlah varian skor item }
\end{aligned}
$$

Jika nilai alpha $>0,7$ artinya reliabilitas mencukupi (sufficient reliability) sementara jika alpha > 0,80 ini mensugestikan seluruh item reliabel dan seluruh tes secara konsisten secara internal karena memiliki reliabilitas yang kuat.[8]

\section{PEMBAHASAN} Gambar 1.

Metode Penelitian yang digunakan dalam pengembangan aplikasi adalah Metode Waterfall ditunjukkan pada

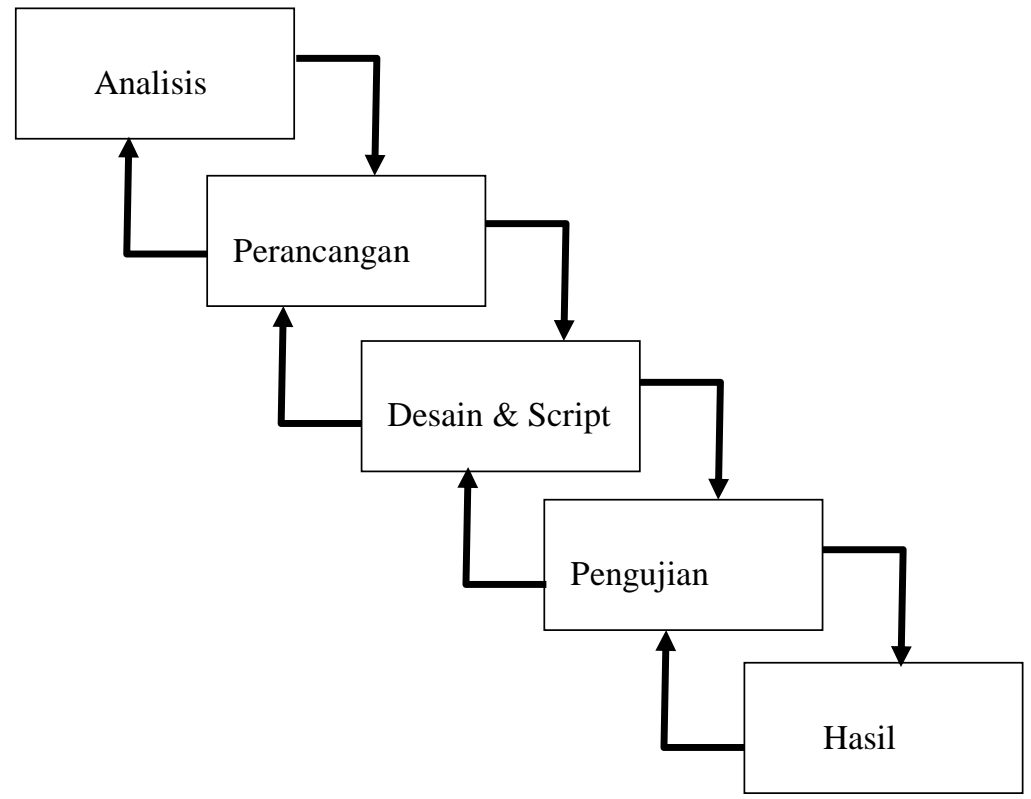

Gambar 1. Metode Waterfall Dalam Pengembangan Aplikasi AR Berbasis Mobile Di Ruang Pamer Museum Sangiran

\subsection{Tahap Analisis}

Analisis dilakukan melalui observasi langsung ke lokasi dan interview dengan pengelola museum berkaitan dengan keunikan atau ciri khusus dari setiap benda purba yang dipamerkan. Analisis sangat diperlukan untuk menentukan jenis marker yang akan digunakan. Klasifikasi marker dapat digolongkan yaitu marker cetak berupa gambar cetak (black-white) seperti text marker, ubi marker dan fudision marker dan marker bebas (markerless) berupa gambar foto dan objek 3D benda purba. Faktor yang mempengaruhi kamera dalam mengenali objek untuk memunculkan informasi virtual yaitu pencahayaan (lumination), jarak kamera terhadap objek, sudut kamera terhadap objek, resolusi kamera, oclution shape (bayangan kamera), tilt (pergerakan kamera).

\subsection{Tahap Perancangan}

Dalam tahap ini ditentukan jenis hardware maupun software yang diperlukan dalam membuat aplikasi Augmented reality Museum Sangiran. Hardware yang dibutuhkan dengan spesifikasi Processor Intel zcore i5, RAM : 4GB. Dan hardware untuk ujicoba berupa mobilephone dengan spesifikasi Processor quad core 1,2GHz, 1GB memori, kamera 8MP dan Android OS v4.2.2 (Jelly Bean). Software yang digunakan untuk membuat aplikasi adalah 3D Studio Max untuk menghasilkan file 3D .fbx, Unity $3 D$ untuk menggabungkan file 3D, gambar, animasi, video, suara dan file script sehingga menjadi aplikasi augmented reality. Perancangan system tracking marker seperti Gambar 2. 


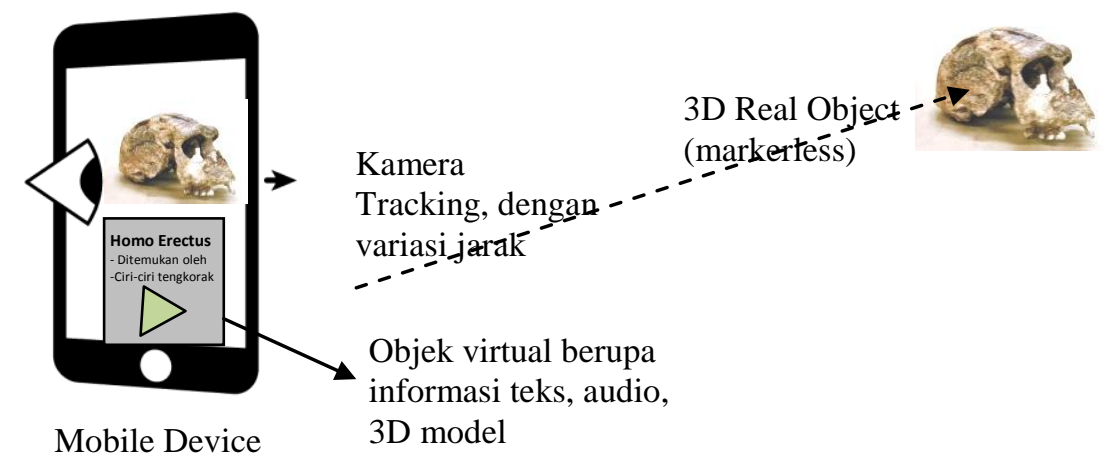

Gambar 2. Perancangan Implementasi Aplikasi Augmented reality Mobile Guide Museum Sangiran

\subsection{Tahap Desain Dan Script}

Pembuatan objek 3D dilakukan dengan bantuan software 3D Studio Max, dengan menyesuaikan bentuk dari berbagai posisi. Kemudian untuk tekstur material dibuat dengan mencuplik gambar aslinya kemudian dijadikan material pada objek 3D. Pembuatan objek 3D benda purbakala seperti pada Gambar 3.

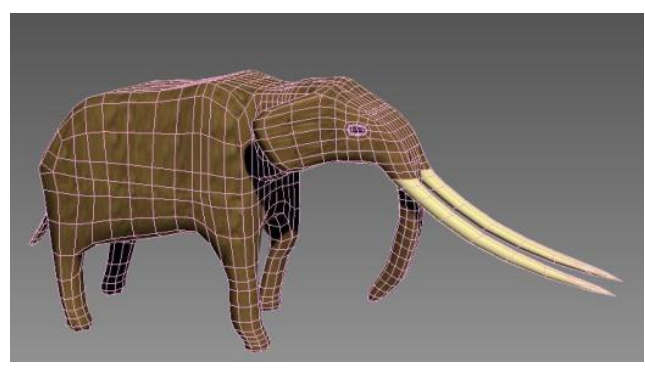

\section{Gambar 3. Model Objek 3D Gajah Purba}

Pembuatan marker bertujuan sebagai referensi image target dalam aplikasi AR, apabila image target dikenali saat tracking marker maka akan memunculkan objek virtual 3D saat itu juga. Marker yang digunakan bersifat markerless yaitu berupa objek pamer benda purbakala yang bersangkutan seperti Gambar 4.
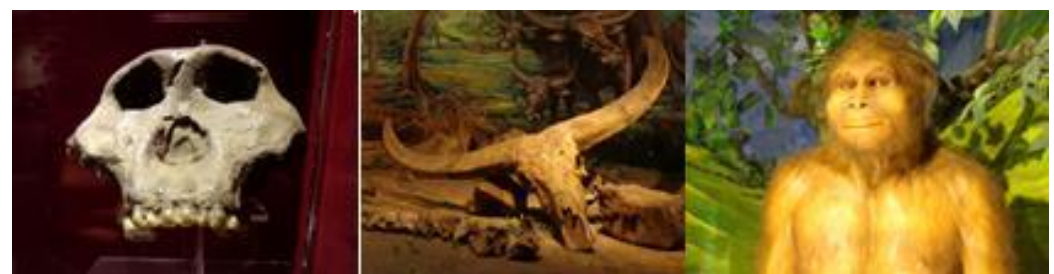

Gambar 4. Desain Markerless Berupa Objek Pamer Yang Berada Dilokasi Ruang Pamer Museum Sangiran Untuk Memunculkan Objek Virtual Berupa Informasi Yang Bersangkutan

Pembuatan marker sebagai image target seperti ditunjukkan pada Gambar 5, dilakukan menggunakan tool Vuforia dengan tipe target yaitu single image dan lebar marker 800 pixel gambar dan tinggi menyesuaikan secara proporsional.

Dalam Vuforia seperti pada Gambar 6, image target yang mudah dikenali saat tracking marker ditandai dengan jumlah feature berupa rating yaitu tanda star (bintang 5), apabila marker memiliki nilai full rating ( 5 bintang) maka marker tersebut sangat mudah dikenali saat tracking objek, dan sebaliknya.

Dalam tahap script dilakukan untuk mengatur keselarasan kemunculan objek virtual dengan marker yang telah ditentukan. Dalam penelitian ini terdapat 37 markerless yang telah didaftarkan dalam Vuforia. Masing-masing tampilan virtual dilengkapi tombol interaksi berupa tombol audio untuk mengaktifkan dan mennaktifkan audio dubbing dan tombol navigasi lainnya. 


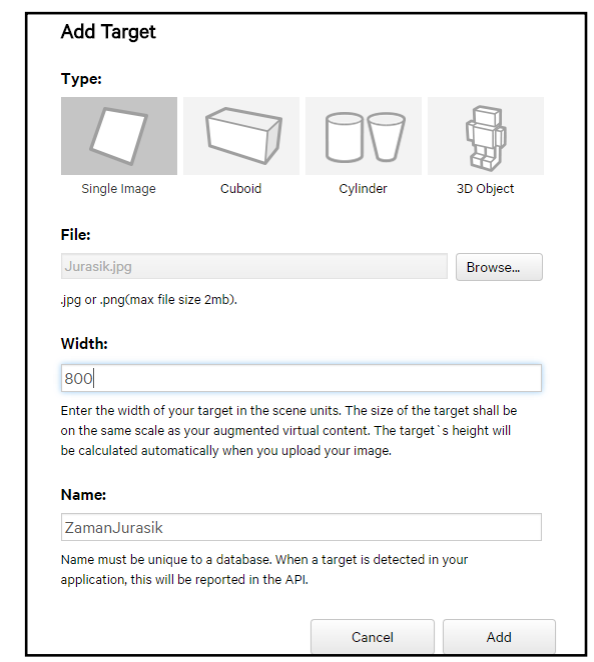

Gambar 5. Proses Pembuatan Marker Sebagai Image Target Menggunakan Vuforia

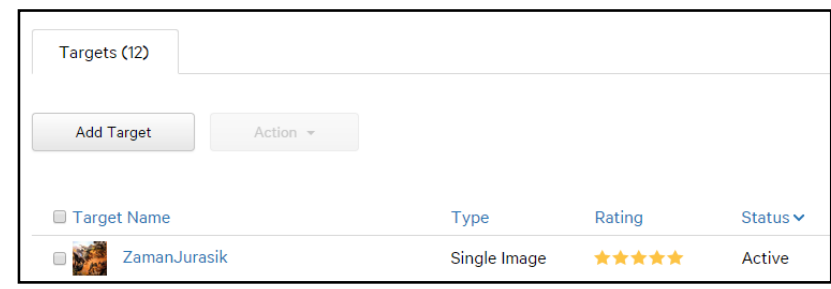

Gambar 6. Feature Marker Dengan Nilai Full Rating Pada Vuforia

\subsection{Tahap Pengujian}

Dalam tahap pengujian dilakukan dengan mengujikan langsung aplikasi untuk tracking markerless langsung di ruang pamer Museum sangiran dan kemunculan objek virtual seperti ditunjukkan Gambar 7. Dari 37 image target yang didaftarkan aplikasi mampu mengenali target secara riel time sebanyak 26 markerless hal ini dikarenakan setelah dikonfirmasi ke pihak museum pernah museum dimaintenance atau dibersihakan sehingga mempengaruhi kondisi pencahayaan dalam ruangan dan posisi benda bergeser yang mengakibatkan kemampuan tracking berkurang.

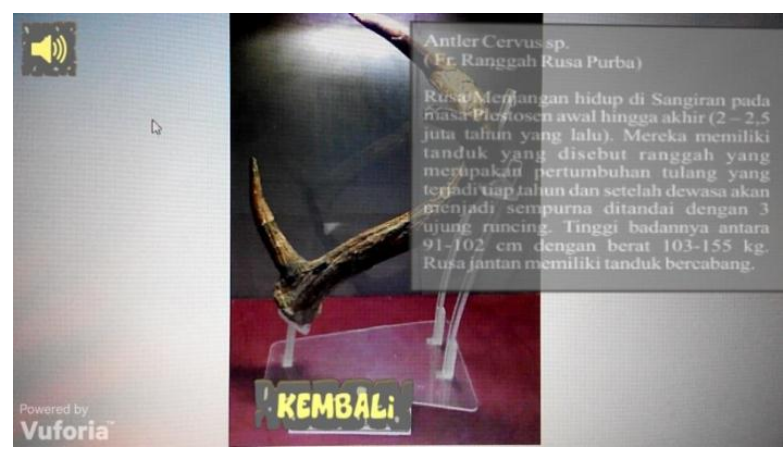

Gambar 7. Implementasi Objek Antler Cervus sp Yang Di Tracking Menggunakan Aplikasi Android Melalui Handphone

\subsection{Hasil Pengolahan Angket Kuisioner}

Survey kuisioner dilakukan terhadap 33 responden, yang terdiri dari 1 responden berpendidikan SD, 1 responden berpendidikan SMP, 8 responden berpendidikan SMA, 9 responden berpendidikan D3, 12 responden berpendidikan S1 dan 2 responden berpendidikan S2. Data hasil kuisioner digali dengan menggunakan instrumen angket. Angket terdiri atas beberapa pertanyaan berikut:

1. Ketertarikan terhadap aplikasi (1 pertanyaan)

2. Kemudahan mendapatkan informasi (1 pertanyaan) 
3. Kemudahan penggunaan navigasi (1 pertanyaan)

4. Interaktifitas aplikasi (1 pertanyaan)

5. Inovasi aplikasi (1 pertanyaan)

Skala penilaian dalam butir pertanyaan menggunakan skala Likert dengan 6 skala nilai, yaitu sangat tidak setuju (1), tidak setuju (2), agak tidak setuju (3), agak setuju (4), setuju (5) dan sangat setuju (6).Hasil perhitungan analisis validitas dan reliabilitas angket disajikan dalam lampiran (perhitungan dilakukan dengan menggunakan program Excel). Dari perhitungan validitas butir pertanyaan ditunjukkan bahwa semua butir pertanyaan yang diajukan dinyatakan valid karena semua koefisien korelasi produk momen tiap butir pertanyaan diatas nilai 0.54 , sedangkan analisis reliabilitas ditunjukkan dengan nilai alpha cronbach sebesar 0.97. Dengan demikian instrumen angket dinyatakan sudah valid dan reliable Selanjutnya tanggapan responden dalam menanggapi aplikasi Augmeneted Reality berupa media ajar interaktif menunjukkan bahwa dalam aspek ketertarikan pengunjung terhadap aplikasi ditunjukkan pada Gambar 8 .

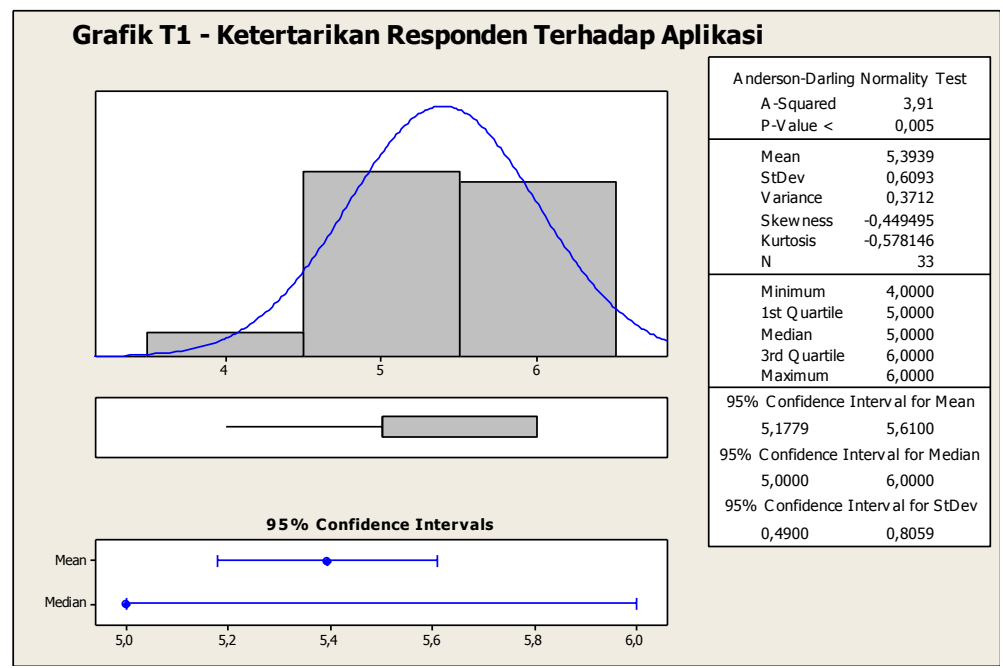

Gambar 8. Grafik Ketertarikan Responden Terhadap Aplikasi

Responden memberikan nilai rerata skor kejelasan tujuan pembelajaran sebesar 5,39 (dari max 6) dengan nilai terendah 4. Hal ini menunjukkan bahwa responden menyatakan bahwa Aplikasi AR Mobile Guide Museum Sangiran dinyatakan memiliki ketertarikan terhadap responden yang sangat baik. Prosentase untuk aspek ketertarikan responden terhadap aplikasi yaitu jumlah setuju-sangat setuju bernilai 93\%. Dalam aspek kemudahan pengunjung mendapatkan informasi ditunjukkan pada Gambar 9.

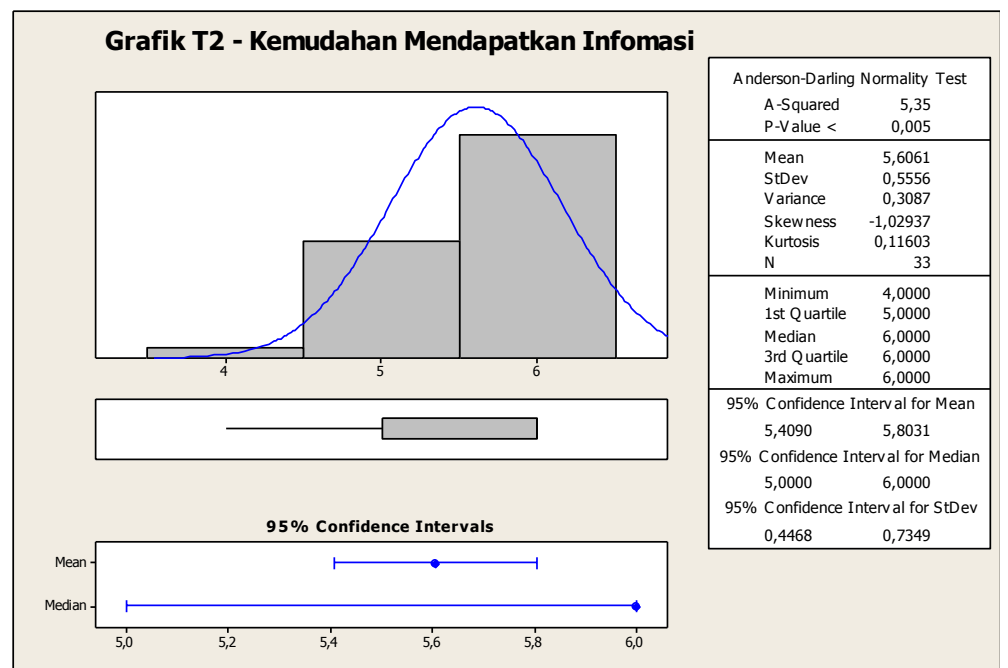

Gambar 9. Grafik Kemudahan Responden Mendapatkan Informasi 
Responden memberikan nilai rerata skor kemudahan mendapatkan informasi sebesar 5,61 (dari max 6) dengan nilai terendah 4. Hal ini menunjukkan bahwa responden menyatakan bahwa Aplikasi AR Mobile Guide Museum Sangiran dinyatakan memiliki kemudahan dalam mendapatkan informasi yang sangat baik. Prosentase untuk aspek kemudahan mendapatkan informasi oleh responden yaitu jumlah setuju-sangat setuju bernilai 97\%. Dalam aspek kemudahan pengunung dalam penggunaan navigasi ditunjukkan pada Gambar 10.

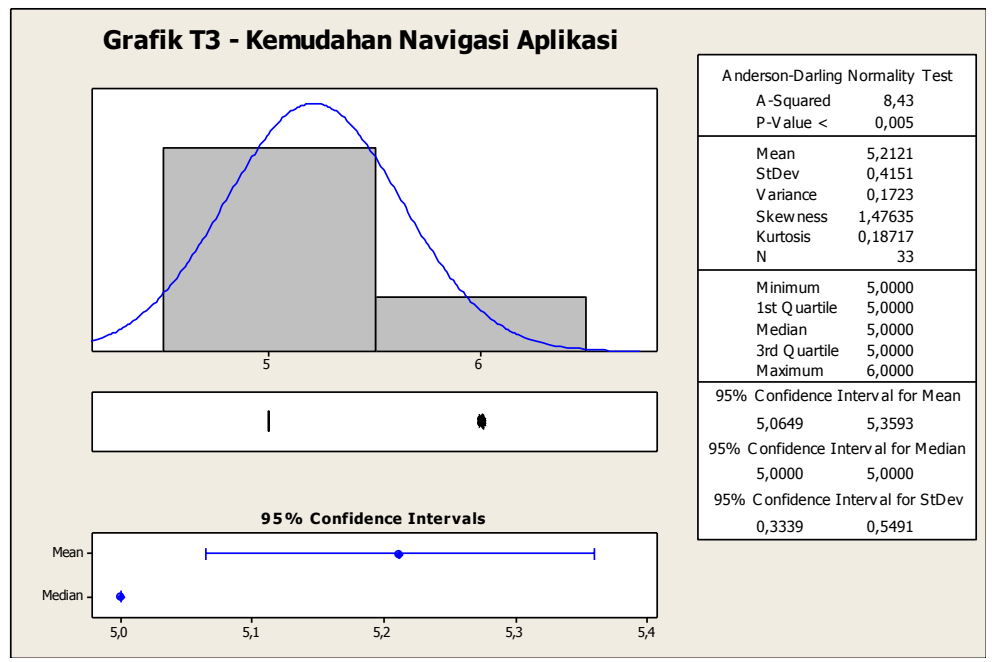

Gambar 10. Grafik Kemudahan Responden Menggunakan Navigasi

Responden memberikan nilai rerata skor kejelasan tujuan pembelajaran sebesar 5,21 (dari max 6) dengan nilai terendah 5. Hal ini menunjukkan bahwa responden menyatakan bahwa Aplikasi AR Mobile Guide Museum Sangiran dinyatakan memiliki kemudahan penggunaan navigasi terhadap responden yang sangat baik. Prosentase untuk aspek kemudahan navigasi responden yaitu jumlah setuju-sangat setuju bernilai 100\%. Dalam aspek interaktifitas aplikasi ditunjukkan pada Gambar 11.

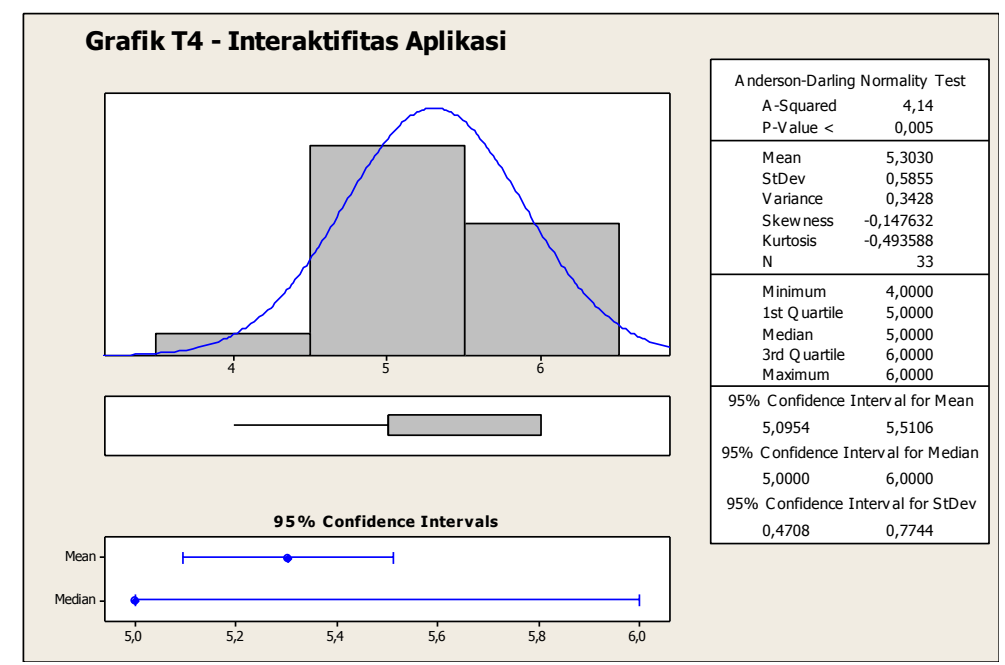

Gambar 11. Grafik Interaktifitas Aplikasi Oleh Responden

Responden memberikan nilai rerata skor interaktifitas aplikasi sebesar 5,30 (dari max 6) dengan nilai terendah 4. Hal ini menunjukkan bahwa responden menyatakan bahwa Aplikasi AR Mobile Guide Museum Sangiran dinyatakan memiliki interaktifitas terhadap responden yang sangat baik. Prosentase untuk aspek interaktifitas aplikasi yaitu jumlah setuju-sangat setuju bernilai 94\%. Dalam aspek inovasi terhadap pengembangan aplikasi ditunjukkan pada Gambar 12. 


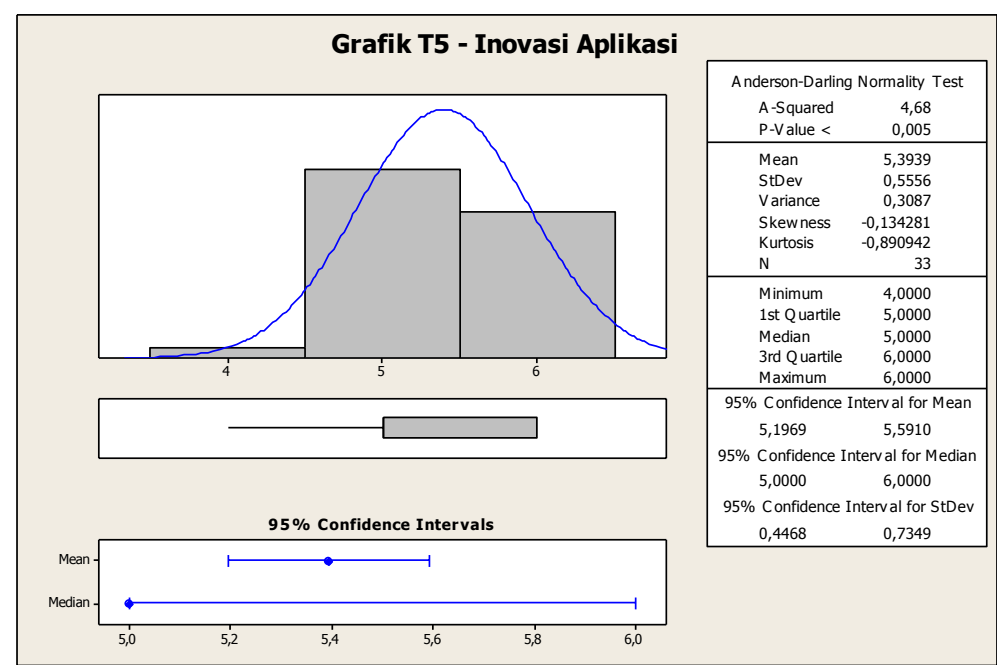

Gambar 12. Grafik Kemanfaatan Aplikasi Terhadap Responden

Responden memberikan nilai rerata skor inovasi aplikasi sebesar 5,39 (dari max 6) dengan nilai terendah 4. Hal ini menunjukkan bahwa responden menyatakan bahwa Aplikasi AR Mobile Guide Museum Sangiran dinyatakan memiliki inovasi yang sangat baik. Prosentase untuk aspek inovasi aplikasi yaitu jumlah setuju-sangat setuju bernilai $97 \%$.

\section{KESIMPULAN}

Penelitian yang dilakukan telah menghasilkan aplikasi Mobile Guide Augmented reality Museum Sangiran yang mengemas informasi pelengkap dari objek pamer. Aplikasi mampu melakukan tracking marker dalam jarak terpendek $30 \mathrm{~cm}$. Hasil analisis berupa validitas dan realibilitas menghasilkan alpha cronbach 0,97 sehingga semua butir pertanyaan dinyatakan valid dan reliable. Tanggapan responden terhadap aplikasi Mobile Guide Museum Sangiran diwujudkan dalam 5 aspek yaitu aspek ketertarikan terhadap aplikasi bernilai setuju-sangat setuju 93\%, aspek kemudahan mendapatkan informasi bernilai setuju-sangat setuju 97\%, aspek kemudahan navigasi bernilai setuju-sangat setuju 100\%, aspek interaktifitas aplikasi bernilai setuju-sangat setuju 94\%, dan aspek inovasi aplikasi bernilai setuju-sangat setuju $97 \%$.

\section{DAFTAR PUSTAKA}

[1] Widianto, H. 2010. Jejak Langkah Setelah Sangiran. Cetakan 1. Balai Pelestarian Situs Manusia Purba Sangiran.

[2] Widianto, H., Simanjuntak, T. 2009. Sangiran Menjawab Dunia, Cetakan 2. Balai Pelestarian Situs Manusia Purba Sangiran,.

[3] Rekimoto, J., Ayatsuka, Y. 2000. Cybercode: Designing Augmented reality Environments with Visual Tags, Proceedings of Designing Augmented reality Environments.

[4] Lazuardi, S. 2012. Augmented reality : Masa Depan Interaktivitas, [Online] http://tekno.kompas.com/read/2012/04/09/ 12354384/Augmented.Reality.Masa.Depan.Interaktivitas. [23 mei 2012]

[5] Jing, C., Junwei, G. Yongtian, W. 2011. Mobile Augmented Reality System For Personal Museum Tour Guide Applications, CCWMC2011

[6] Nassar, MA. 2010. An Augmented Reality Exhibition Guide for the iPhone, 2010 International Conference on User Science Engineering (i-USEr)

[7] Sugiyono. 2007. Metode Penelitian Administrasi. Bandung: Alfabeta.

[8] Rainsch, S. 2004. Dynamic Strategic Analysis: Demystifying Simple Success Strategies (Wiesbaden: Deutscher Universitasts-Verlag) p.167. 